\title{
Sacred and profane in the religiosity of Brahmanical Banaras: past to present
}

\begin{abstract}
Banaras or Varanasi, name of ancient city Kasi, located on the western bank of the Ganges is known as unique ancient historical city; one of the oldest continuously settled cities of the world. Its origin is considered to be timeless. The vast cultural zone of Varanasi has been divided into two tendencies of occupation: the banks of the major river Ganga and the habitats and the habitats of the inland of the smaller river streams. These two have been termed as the "Kasi Varanasi" and the "Varanasi-Sarnath" regions and both these regions appear to have historical and religious significance. We do have Islamic and other religions presence in Banaras but our task as present is to discuss the sacred and profane in the religiosity of Brahmanical Banaras and it's linkages since ancient times. This subject has been approached with a dynamic perspective; through assimilation of past and present in reference to the archaeology, mythology, geography, art and history and cultures as well as other sources of information on the lives and history of people: men and women. The study focuses on data collection, ranging from theoretical to narrations, storytelling, observation of rituals, site visits (City, Temples, Ghats and Punchakoshi pilgrimage) which becomes important to integrate complex issues of religion and socio-economic culture, specific objects, and landscapes and structures.
\end{abstract}

Keywords: Kasi, Banaras, Varanasi, ritual, religion, culture
Volume 4 Issue 3 - 2019

\author{
Vijaya Laxmi Singh \\ Associate Professor, Faculty of Social Sciences, University of \\ Delhi, India
}

Correspondence: Vijaya Laxmi Singh, Associate Professor, Faculty of Social Sciences, University of Delhi, Delhi, India, Email ddvijayalaxmisingh@gmail.com

Received: March 07, 2019 | Published: June 13,2019

\section{Introduction}

\section{Research methodology and historiography}

Banaras, a pilgrim city is widely acknowledged as a unique ancient Indian historical city. It also exhibits the changing patterns and movements in course of history and how the equilibrium between religion and power relations through caste and other organization and services to the religious structures has been maintained. Gender role analysis point towards participation of women in religious life, many times subservient but trying to manage space for themselves. The subject Sacred and profane in the religiosity of Banaras has been approached with a dynamic perspective; through assimilation of past and present using the archaeology, mythology, geography, art and history and cultures as well as other sources of information on the lives and history of people: men and women. The study focuses on data collection, ranging from theoretical to narrations, storytelling, site visits and observation of rituals which becomes important to integrate complex issues of religion and culture specific objects, and landscapes and structures. Inspired chiefly by Sanskrit religious texts and other textual sources and shaped largely by the urban constructs evidence in the archaeological materials and artifacts I have tried to build composite perspectives in this area of study pointing towards the religiosity of the city based on sacred and profane activities. I have used qualitative as well as quantitative research tools for data collection and interpretations. Varanasi has been very prominent city of Ancient India and this work enlightens the past through present eyes. The subject is magnetic and also important for our social bearing. The terminology Tirtha, a place as believed, where one can practice religion and immediately reap the fruits of its liberation, has been discussed. We have used Banaras, Varanasi or Kasi interchangeably as the name of the city and Varuna and Barna as the name of the river and Visheswara and Vishvanath temple.

Banaras or Varanasi, name of ancient city Kasi, located on the western bank of the Ganges is known as unique ancient historical city; one of the oldest continuously settled cities of the world. Its origin is considered to be timeless. Allusions to Kasi are abundant in ancient Sanskrit literature. The Puranic traditions have documented Siva's connection with Kasi. Vayu and Brahmanda Purana dated from fourth to sixth centuries $\mathrm{CE}$ describes how Siva arrived at Kasi and drove away and subjugated the Yakshas and Ganas who had occupied the city and later these Yakshas were sent to fight with king Divodasa of Kasi. Matsya Purana dated between seventh and twelfth Centuries contains Kasi Mahatmya which mentions the ancient lingams of the city and also its major Tirthas including the famous five situated on the river, Dasasvamedha, Lolarka, Adi Kesava, Panch Ganga and Manikarnika. Sanskrit text Skanda Purana's Kasikhanda points that Kasi is the ultimate place of origins, a place created by Siva" when there was neither the sphere of the earth nor the creation of water. ${ }^{1}$ Purana exalted Kasi as Siva's city except for Narada Purana dated around twelfth century where the famous Vaisnava temple Bindu Mahadeva finds mention along with discussion on Vaisnava cult. Kasi in its divine perspective is a "microcosm of the universe" where "creation is continually replayed". ${ }^{2}$ It is also known as luminous city, ${ }^{3}$ red space, ${ }^{4}$ pilgrimage place, ${ }^{5}$ City of Death, "City of Antiquity"1 as addressed by various historians. It is believed that since area was mostly marshy and full of tall grasses of kush and kas varieties, it came to be known as Kasi, as rivers and trees had played very important role in the life and philosophy of Indian people. Kasi's physical antecedents go back to Vedas as river Varanavati (Varuna) has been

${ }^{1}$ Skanda Purana Pt. 10-11, Kasikhanda; 1996; 1997. Translated and Annotated by GV Tagare, Delhi, 26-28.

${ }^{2}$ Parry Jonathan P. Death in Banaras. Cambridge; 1994. p. 11,32. ${ }^{3}$ Diana LEck. Banaras City of Lights. Columbia; 1999. 1 p.

${ }^{4}$ Kane PV. History of Dharmasastra. Vol. IV, Bhandarkar Oriental Research Institute, Poona, 3rd ed. 1991, p. 619; Havell EB. Benaras: The Sacred City, Sketches of Hindu Life and Religion, London, Glassgow, Bombay, 1905; Rana PB Singh. Banaras: Making of India's Heritage City, Cambridge, UK, 10-1443813214, Singh, see Rana PB. Banaras, the Cultural Capital of India: Visioning Cultural Heritage and Planning. SANDHI, A Journal of Interfacing Science-Heritage and Technology-Tradition of India. 2015;1(1):100-122. ${ }^{5}$ Kane PV. History of Dharmasastra. Vol. IV, 619 p.

${ }^{6}$ Perry Jonathan P. Death in Banaras. Cambridge University Press. 1994. 11 p. 
mentioned in Atharvaveda. ${ }^{7}$ Banaras is described by MA Sherring, a long term emissary of the London Missionary Society in the city as 'a city of no mean antiquity. He writes that twenty five Centuries ago, at the least, it was famous. When Babylon was struggling with Niveh for supremacy, when Tyre was planning her colonies, when Athens was growing its strength, before Rome had become known, or Greece had contended with Persia, or Cyrus had ceded luster to the Persian monarchy or Nebuchandenzzar had captured Jerusalem, and the inhabitants of Judea had been carried into captivity, she had already risen to greatness, if not to glory. ${ }^{2}$ The archaeological excavations of the extensive mounds of Rajghat at the confluence of Barna (Varuna) and Ganges brought to light a continuous cultural sequence from about $1000 \mathrm{BC}$ to the modern times. The excavations have revealed an enormous clay rampart dating to $8^{\text {th }}-7^{\text {th }} \mathrm{C} B C$. It is believed to have been built directly over natural soils by piling up dug up clay to form thick and compact wall with pronounced slope towards Ganges. ${ }^{8}$ Recent analysis of phosphates of soil of Varanasi suggests an age of 2800 years, which makes it one of the ancient and continuously occupied cities of the world. ${ }^{3}$ Kasi was an imperial power in the pre Buddhist times, with Vatsa in its west, Kosala on the north and Magadha in the East. ${ }^{9}$ The archaeological research on complex history of Banaras is still in infancy, but Kasi being an ancient Tirtha or pilgrimage place and also at the crossroads for than one and a half decade, developed as a major trading centre for the Guptas in $4^{\text {th }}-5^{\text {th }}$ century as it became junction for east-west trade route along the Ganges and also connected through north- south route to Kathmandu. ${ }^{10}$ There are two traditions followed here, Shastric (scriptural) and laukik (practical), Shastrik traditions are high culture or orthodox tradition and laukik traditions are heterodox traditions which are considered to be low. And there has always been tension between the followers of the two groups, one following orthodox Brahmanical culture and the other carrying out tantric practices as they are engaged in the construction of their own sacred spaces. The tension is less in case of goddesses in folk traditions who were slowly incorporated in the Brahmanical tradition through the establishment of shrines, temples and temple complexes and through introduction of new images such as of Goddess Kali, Durga etc. Kasi Khanda is the main source of information on goddesses in Kasi which had listed 324 forms of Goddesses in Kasi categorized into several groups, i.e. 96 Shaktis,8 Ksetra-rakshini,64 Yoginis,9 Durgas,12 Gauris,12 Matrakas, 9 Candis, 9 Kshetra Devis, 9 Devis on Panchakroshi route, ${ }^{11}$ 12 independent Devis, 42 Loukik Devis(folk). ${ }^{12}$ But today the number of Devis has reduced. Kasi khanda also describes 324 forms of Siva and all goddesses are represented with their male partners i.e. in some form of Siva. In the remains of Rajghat excavations ${ }^{13}$ such as ring stones and circular discs which are generally associated with goddess worship have been found. On one ring stone carved figure of Devi has been discovered..$^{14}$ Varanasi or Kasi is a Tirtha where countless

\footnotetext{
${ }^{7}$ Motichandra Kasi ka Itihas (Hindi). Vishwavidyalaya Prakashan (2 ${ }^{\text {nd }}$ Edition). Varanasi; 1985. 21 p.

${ }^{8}$ Narain AK, TN Roy. Excavations at Rajghat (1957-58 and 1960-65). BHU Varanasi. 1976.

${ }^{9}$ Anguttara. Vol. I, p. 213, Vol. IV, pp.252,256,260.

${ }^{10}$ Motichandra. Trade and Trade Routes in Ancient India. Delhi: Abhinav Publication; 1977. $168 \mathrm{p}$.

${ }^{11}$ I performed Panchkroshi yatra in the month of March 2017 and found that not all of these devis' shrines exist today, this may be because of change of route or due to development in this area.

${ }^{12}$ Skanda Purana Pt. 10-11, Kasikhanda, 1996;1997. Translated and Annotated by GV. Tagare, Motilal Banarasi Das, Delhi, 26-28.

${ }^{13}$ Narain AK, TN Roy. Excavations at Rajghat (1957-58 and 1960-65). Banaras Hindu University, Varanasi, 1976. 14 p.

${ }^{14}$ Narain AK, TN Roy. Excavations at Rajghat (1957-58 and 1960-65). Banaras
}

generation of travelers or pilgrims may have crossed the river at a particular spot, they might have stayed there prior to crossing, also bathed (act of bathing is considered to be ritual significance) making it a Tirtha place. Traders, priests and merchants may have congregated there to provide services for the travelers.

\section{Sources}

Varanasi (Banaras) is reflected in the statement of renowned scholar PV Kane ${ }^{15}$ in History of Dharmasastra (IV) as: "there is hardly any city in the world that can claim greater antiquity and greater popular veneration than Banaras. Banaras has been holy city for thirty Centuries. No city in India arouses religious emotions of Hindus as Kasi does." Kasi (Banaras) is mentioned as sacred place in Vedas, ${ }^{16}$ Puranas, ${ }^{17}$ Ramayana ${ }^{18}$ and Mahabharata, ${ }^{19}$ and also in Jaina and Buddhist texts. ${ }^{20}$ The glimpse of earliest human occupation in Varanasi is from Atharva Veda, ${ }^{21}$ is that of Kasis (meaning bright), ${ }^{22}$ the indigenous tribes who lived in Varanasi region, it is because of this the region was known as Kasi. ${ }^{4}$ This Kasi (Varanasi or Banaras) of ancient times carries its glory even today. The Puranas are a mixture of myth and reality, hence coins, inscriptions, architecture and relics discovered in Rajghat, Sarnath and elsewhere are used by historians to corroborate the facts and these are reliable sources for history of Varanasi. The temples and the ghats are vast area of space for religious and cultural life of people and the city. Ancient Sanskrit literature and archaeological excavations are source for ancient Varanasi and Persian literature, official records and correspondence are important for the medieval history of the City, while corpora of Government records and various other publications in Indian and European languages are valuable as source material for a modern history. Travel accounts left by ancient travellers i.e. the travel accounts of Fa- Hien and HiuenTsang of China in 5th century and 7th century respectively; medieval accounts of Al-Beruni in 11th century and modern travellers i.e. Ralph Fitch and Reginald Heber of England, in 16th century and 19th century, Jean Baptiste Tavernier and Francois Bernier of France in 17th century ; Nicola Manucci of Italy in 17th century, Malachouski of Poland in 19th century; John B. Ireland and Mark Twain in 19th century, and Vijayram Sen in 18th century and Enugula Veeraswamy in 19th century from within the country and abroad are additional sources of information which throw light on the Varanasi of their respective times. The records preserved by the City's pandas, pandits, rais and hereditary bankers are also valuable source of information. Varanasi is also exhibited through the paintings of Western artists, the travel-accounts of these artists and also of the British East India Company's civil and military officers and other Western travellers. This picturesque centre of oriental culture, caught the imagination of both painters and travellers, and thus became a major theme in their composition, which, in turn, attracted other Westerners here. It is said that Max Muller, the European Indologist, during his school days was moved by a picture of riverfront of Varanasi in his school book. ${ }^{23}$

Hindu University, Varanasi, 1976. p. 14-15.

${ }^{15}$ Kane PV. History of Dharmasastra, Vol. IV, Oriental Research Institute, Poona, 3rd ed. 1991,618

${ }^{16}$ Atharva Veda. 4,7.1, ed. Vishva Bandhu, VVRI, Hoshyarpur, 1961.

${ }^{17}$ Vishnu Purana V. 34.1 .4 , p. $21-40$, Venkateshwara Press Mumbai, samvat 1689; Brahmanda , iii, 67,26-62.

${ }^{18}$ Ramayana, Adikhanda $13^{\text {th }}$ sarga, Uttarakhanda $56^{\text {th }} \mathrm{ch}, 81.25$

${ }^{19}$ Mahabharata V. 117, Critical Edition. Pune. 1927-66.

${ }^{20}$ Mahavastu E Senart ed, Vol III, Paris, 1982-97, p. 402.

${ }^{21}$ V.22.14 cf. Vedic Index, II, p. 116.

${ }^{22}$ Imperial Gazetteer of India. V. 7, p. 187.

${ }^{23}$ Medhasananda Swami, Varanasi at the Cross Roads: The Panoramic view of Early modern Varanasi and Survey of its Transition, Ram Krishna Mission Institute of Culture, Kolkota, 2002. 
In addition to these, monographs written by various authors in their contemporary setting are valuable sources. I am citing here few of them. James Prisep's 'Benaras Illustrated in A Series of Drawings' was first published in 1833 which has many maps and illustrations giving vivid picture of sacred city. MA. Sherring's Benares: The Sacred City of the Hindus, in 1869-a pioneering work being the first such monograph on the City's history and culture ever published in a European language; J. Murdoch's Kasi or Benares, in 1894; A. Parker's A Handbook of Benares, in 1895; E.B. Havel's Benares: The Sacred City, in 1905; C.P. Cape's Benares: The Stronghold of Hinduism, in 1908 and E. Greave's Kasi, in 1909 are few examples. Motichandra's massive works of scholarship 'Kasi Ka Itihas'(1962), Kuber Nath Sukul's Varanasi Down the Ages in 1974, Martin Gaenszle and Jorg Gengnagel edited Visualizing Spaad in Banaras (2008). Banaras: Urban Forms and Cultural Histories edited by Michael Dodson in 2012, Singh, Rana PB., Towards the Pilgrimage Archetype. The Panchakrosi Yatra of Banaras, Indica Books, Varanasi, 2002 etc. are inexhaustible source of information particularly valuable on political cultural and social history of the city.

Scholars across the world have discussed on sacred secular continuum impacting the socio cultural life of the people in various regions. Since the first quarter of the 20th century many historians of religions have accepted the notion of the sacred and of sacred events, places, people, and acts as being central in religious life if not indeed the essential reality in religious life. ${ }^{24}$ The sacredness of Varanasi's location and topography has been extolled in scriptures since antiquity. Its multiple belief systems, its cultural patterns, spatial territories and archaeological discoveries are so enormous that despite the works of several scholars for Centuries we still carve for knowledge about the magnificence of Banaras.

\section{Space, archaeology and architecture in the religiosity of Brahmanical Banaras}

We should first understand the geography and structure of the city to understand the sacred and profane activities in Varanasi. The Master Plan of Varanasi-2011 identifies five heritage zones in the city:- The Ganges River and the Riverfront Heritage ZoneDurgakund-Sankatmochan Area-Kamachcha-Bhelupura Area-Kabir Math (Lahartara) Area-Sarnath. Recently Varanasi is divided into five zones ${ }^{25}$ based on the characteristics of the city. The Core zone or heart of the city (inner part of the city near ghats) where all main activities: economic activities, religious activities and tourism attraction prevail has a very high density. Sarnath is situated in the Trans Varuna zone, which is a Buddhist pilgrimage. The south Varuna zone is the old unplanned residential area of the city. Banaras Hindu University with diverse student population is located in the South Asi zone. Ramnagar is located in the Trans-Ganga zone which is yet to be well connected with the city. The city is a mosaic of the various religious groups and their traditions. In the city alone, there are over 3300 Hindu shrines and temples, about 1388 Muslim shrines and mosques, 12 churches, 3 Jain temples, 9 Buddhist temples, 32 Sikh temples (gurudvaras) and several other sacred sites and places. ${ }^{5}$ Banaras will always possess supreme interest as a chief centre of the evolution of two great world religions: Brahmanism and Buddhism but while the development of Buddhism can be to some extent mapped out with exact dates and events, the history of Brahmanism must always be regarded from

\footnotetext{
${ }^{24} \mathrm{https}$ ://www.britannica.com/contributor/Frederick-J-Streng/2876

${ }^{25}$ Sustainable Development of a Heritage City. Varanasi; p. 7-8, School of Planning and Architecture Report.
}

different standpoint. ${ }^{4}$ Vidula Jaiswal ${ }^{26}$ also divides the vast cultural zone of ancient Varanasi into two tendencies of occupation: the banks of the major river Ganga and the habitats and the habitats of the inland of the smaller river streams. These two have been termed as the "Kasi Varanasi" and the "Varanasi-Sarnath" regions and both these regions appear to have historical and religious significance The religious landscape of Kasi Varanasi was resurrected on the basis of a ritual geography specified in various Puranas. ${ }^{27}$ There is no mention of Varanasi as civic unit in ancient Hindu literature and invariably it is mentioned as Dharma Kestra (religious unit) and there are four names used in Purana's viz. Kasi (between Madhyameswara to Delhi Vinayak- a radius about 10 miles and it is this geographical unit which is now circumambulated in the Punchkroshi pilgrimage), Varanasi( between Varana and Asi rivers about 4 to $5 \mathrm{kms}$ NE and SW each), ${ }^{28}$ Avimukta (one krosh on all sides of Madhyamesvara as discussed in Skanda Purana) and Antargriha (between Manikarnakesvarain the East and Gokarnesvara in the west and Bharabhutesvara in the north and Brahmesvara in the South). Each dharmakshetra has exact significant geographical boundaries. ${ }^{29}$ There is one more kshetra called Trikantaka which stands for the triangular area lying between Madhyamesvara, Swarlinesvara and Avimuktesvara. ${ }^{30}$

The historians of religion, culture and civilization generally address the inadequacies of textual sources with respect to their chronologies, perspectives and doctrines and look for use of inscriptions, art historical remains and architecture as additional source of information. In case of Banaras it is popularly believed that the city of Varana is not situated on earth but it stands on the trident of god Siva and that is why it is unique in the three worlds. It is not easy to subscribe to the validity of the legend but however the historians and archaeologists have made an effort to trace three prongs of Siva's trident geographically on the river bank. ${ }^{31}$ The whole city of Banaras is situated on three Kantars (lime concretion) ridges, 50' to 30 ' high, forming the west bank of Ganges. The northern most the Raj hat plateau is the highest one and lies between the Varna Sang am and the Raj hat. The middle one the longest among the three, can be called Dasasvamedha plateau marked by Godawalia Nala, confluencing at Dasasvamedha ghat. The third one may be termed as Asi, lowering at the confluence of that river. ${ }^{32}$

It is fairly established now that Rajghat mounds represent the remains of ancient city of Varanasi. Earlier Sherring was the first one to point out that the old city of Varanasi stood towards north possibly on both sides of the river Varuna where it joins the Ganges. ${ }^{33}$ But the significance of the suggestion was realized by the accidental discovery

${ }^{26}$ Vidula Jayaswal. Ancient Varanasi an Archaeological Perspective. New Delhi: Aryan Book International. 2009, p. 5

${ }^{27}$ Skanda Purana. Pt. 10-11, Kasikhanda; 1996;1997. Translated and Annotated by GV Tagare, Motilal Banarasi Das, Delhi, 26-28.

${ }^{28}$ Lakshmidhara's Tirthavivecanakanda, pp 30-39; The alleged circuit of five kroshas may have given rise to the idea of Punchkroshi Yatra as is suggested by Hans Bakkar, The Avimukteshwara in Varanasi: its Origin and Early Development, in Visualizing Space in Banaras; Images, Maps, and the Practice of Representation; ed by Martin Gaenszle and Jorg Gengnagel, Oxford University Press, Delhi, p 31.

${ }^{29}$ Sukul Kuber Nath. Varanasi down the Ages. Patna, Varanasi; 1974. p. 163-64. ${ }^{30}$ Sukul, Kuber Nath, Varanasi down the Ages. Patna, Varanasi; 1974. p. 164. ${ }^{31}$ Verma TP. Temples of Banaras in LK. Tripathi Ed. Bulletin of the College of Indology. BHU: 1984. p. 195

${ }^{32}$ Verma TP. Temples of Banaras in LK. Tripathi ed. Bulletin of the College of Indology. BHU; 1984. p. 195.

${ }^{33}$ Sherring MA. Benaras, the Sacred City of the Hindus in Ancient and Modern Times. BR Publishing Corporation. Delhi, 1868, reprint 1975. p. 17. 
of the site and subsequent operation of archaeologists on it. In this connection the discovery of seal from Rajghat inscribed in Gupta character with the legend 'Baranasy-adhishthan-adhikaranasya' meaning the seal of the city administration of Varanasi is significant, as it has proved beyond doubt that the mounds discovered at Rajghat in fact represents the site of ancient Varanasi. ${ }^{34}$ There is yet another sealing of the same period reading 'Banarasy-aranyaka-sreni' meaning the guild of foresters of Varanasi which further confirms the above suggestions..$^{35}$ We may visualize Banaras in later Vedic times as one of the first Aryan settlements in the Ganges Valley by clearing the dense forest. The Ganges with river Barna on the north and Asi in the South at that time must have acted as protection from the hostile invasions of fierce aboriginal tribes living in the dense forest. Ganges also may have acted as an easy highway of communication with the older Aryan settlements in the Punjab. The numismatic evidences suggest it formed the part of Gupta Empire. Gold coins of Chandragupta, Kumara Gupta and Skanda Gupta were found in excavations at Rajghat. ${ }^{36}$ Varanasi had occupied a place in Brahmanical religion from Vedic age to the age of Gahadwalas in $12^{\text {th }}$ century. ${ }^{37}$

At present we may classify the urban space in Banaras in three parts: Ganges River and the Ghats and ritual bathing tanks; temples as representations of religious culture and the profane spaces: the lanes (gallis) and chauk. The historicity of the Ghats suggests that majority of the Ghats are associated with legends and mythologies and also, they were continued to be named after deities in most cases till the end of seventeenth century. Again, none of the traditional names of the Ghats were changed throughout Muslim rule, except in one case when Mir Rustam Ali, the Governor of Varanasi, replaced the name of Jarasandha Ghat with his own towards the middle of the eighteenth century. This is also indicative of the fact that despite Muslim invasion and rule and initial destruction of temples, the religiosity of ancient Brahmanical tradition continued to exist. River Ganges was revered since ancient times and had ritualistic merit as well as it played very important role in the settlement history since later Vedic times but we donot find the detailed accounts of the Ghats even kaccha ghats in ancient sources. We have known from the Sanskrit sources that many of the Ghats were named after deities such as Trilochana, Brahma, Durga, Agnishwara, suggesting sacred aspect of the religiosity of the river. The first available work in Sanskrit is Girvanapadamanjari, written by Varadaraja $(1600-1660)^{38}$ which has listed twenty two ghats

${ }^{34}$ Deva Krishna. Excavations at Rajghat near Banaras, Annual Bibliography of Indian History and Indology. Vol. III. 1940. p. 41-51.

${ }^{35}$ Deva Krishna. Excavations at Rajghat near Banaras, Annual Bibliography of Indian History and Indology. Vol. III. 1940. p. 41-51.

${ }^{36}$ Narain AK, TN Roy. Excavations at Rajghat (1957-58 and 1960-65). Banaras Hindu University, Varanasi, 1976. p. 14.

${ }^{37}$ The discovery of an image inscription of Ballala's ninth regnal yearat Sanokhan in the Bhagalpur district(Epigraphia Indica). XXX, p. 78),the reference to Sena king Lakshmana's victory over the kings of Kasi i.e. Gahadvala monarchy( Epigraphia Indica Vol. XXVI, p. 6 \{verse II $\}$, also N.G. Majumdar, Inscription of Bengal, Vol. III, p.11 and to his son raising pillar of victory at Visesvara Kshetra i.e. Varanasi and Triveni i.e. Prayaga or Allahabad(Epigraphia Indica, XXIII. P. 322, verse 12; and the earliest use of Lakshmansena Samvat in the Gaya region (D.C. Sircar, Indian Epigraphy, p.272) suggest that the era succeeded in extending the Epigraphia Indica political influence over Bihar and in invading Eastern UP, Laksmansena was ousted from the western area of his dominions by the Turkish rulers, but continued to rule over (C. 1206$20 \mathrm{AD}$ ) and later his desadndents ruled in East Bengal till $1260 \mathrm{AD}$ (Indian Historical Quaterly Vol. XXIX, p. 73)

${ }^{38}$ Girvanapadmamanjari ed, Umakant Shah, M.S, University, Oriental Series, No. 4, pp. 76. Oriental Institute Baroda, 1960; Medhasananda Swami, Varanasi at the Cross Roads, The Panoramic view of Early modern Varanasi and Survey in the City in the first half of the seventeenth century. In the early part of the nineteenth century, Jayanarayan Ghoshal, in Kasi Parikrama, a Bengali account of Varanasi, recorded the first exhaustive list of seventy Ghats from Asi to Varuna Sangam, few Ghats, such as Shivala, Panchaganga and Gai, which are then known, still exists. ${ }^{39}$ Many Ghats mentioned in his account cannot be identified now. During his time, sixty Ghats were made of stone and among the remaining ten, eight Ghats, namely, Samashan (presently Harishchandra), Rajballav Mashan and Yameshwar, were burning Ghats; and Asi, Gular, Raj, Ducanganj and Sabitabad were cuchha Ghats; and the two remaining Ghats, Telianala and Shahajada were uneven and built of bricks. ${ }^{40}$ Prinsep, in his 1822 map of the City, furnishes a list of fifty-eight Ghats from Asi to Raj Ghat, from the map of the City prepared by Bax, the Collector of Varanasi in 1868, we get a list of fifty-five Ghats Survey of India of 1920 and the Kasi Tirth Sudhar Trust, a body set up in 1926 also prepared a list of Ghats, Kasi Chitra a map prepared by an engineer Govind Chandra Bandopadhyaya around 1938 showed the location of Ghats, but does not include many of the Ghats mentioned earlier. Rambachan Singh prepared a list of ghats around $1970 .{ }^{41}$

The city rises from the western bank of the river Ganges moving towards the north, forming a crescent shape surmounted by irregular buildings of various styles and proportions making the landscape picturesque. The Ghats of Banaras are central to religious life as described by Robert Elliot in Views in The East (1833): "The immense flights of steps, called Ghauts of Benaras, form a great ornament to the river faad of the city; and, in the early part of the day especially, they present a very beautiful, though at the same time, a very awful spectacle. Crowds of people come down to wash in, and also to worship the Ganges." ${ }^{42}$ The Ghats of Banaras lead from Asi Ghats in the south to Adi Kesava Ghat in the north. Conveying his description through his paintings, most notably, "A View of Benares" and "The Ghats at Benares" Hodges produced a display of the Ghats leading to the Ganges where one can view the city through its riverfront. ${ }^{43}$ Daniells drawing of the view of the "Dusasumade Ghat" in 1788 when they passed through Banaras also throw light on majesty of the riverfront. John Murray, a British surgeon in the employ of the East India Company photographed Banaras dating from 1857-58. By the end of the nineteenth century, this picturesque characterization of Banaras through its waterfront dominated the photographic depiction of the city. The imagery in paintings and photographs lent Banaras a unique visual identity displaying the blend of conflicting phenomena: culture and nature, purity and pollution, life and death and soon.

Mapping is visualizing, conceptualizing, recording, representing and creating space graphically. ${ }^{44}$ But in case of Banaras the religious notions such as merit grace, transadndence or liberation at Ghats is very difficult to be represented in maps. Banaras is also represented in the paintings of William and Thomas Daniells and also James

of its Transition, Ram Krishna Mission Institute of Culture, Kolkota, 2002, ISBN 81-87332-18-2.

${ }^{39}$ Ghoshal Jaynarayan. Kasi Prikrama 1906. p. 372.

${ }^{40}$ Ghoshal Jaynarayan. Kasi Prikrama 1906. p. 372.

${ }^{41}$ Medhasananda Swami. Varanasi at the Cross Roads, The Panoramic view of Early modern Varanasi and Survey of its Transition, Ram Krishna Mission Institute of Culture, Kolkota; 2002. p. 331; with the help of the above lists, a comparative table of Ghats during different periods in the history of the City has been prepared and placed in the Appendix of the above book.

${ }^{42}$ Mahajan Jagmohan. Ganga Observed: Foreign Accounts of the River. New Delhi: Virgo Publications; 1994. ISBN 818570-039, p. 76.

${ }^{43}$ Hodges W. Travels in India, During the years 1780,81,82 and 83. London; 1793.

44Cosgrove DE. Social Formation and Symbolic Landscape. Medison: Wisconsin University Press; 1998. 2. p. 
Prinsep.$^{45}$ Prinsep also created a map of the city based on his survey. $\mathrm{He}$ also conducted census of the city based on its people and buildings and also a catalogue of caste and trade. ${ }^{46}$ Prince interpreted city as Hindu religious city with Dominance of Brahmanas and wrote that "the Muselmans apparently form but one-fifth of the population, and are not more numerous than the Brahmans alone; very few of them reside within the City, properly so called, which is almost exclusively Hindu." By beginning his lavish three-volume Benares Illustrated (published between 1831 and 1833) with a sketch of a Brahman sitting, literally, on his Kasi surrounded by the paraphernalia of his religion, Prinsep created the visual reality of his census survey. ${ }^{47}$

\section{Religiosity of temples, ghats and other pilgrim places}

We do not find any temple architecture in early period except at Khandawa in the south west Banaras dated in eleventh twelfth century. ${ }^{48}$ But the association of Banaras with Siva worship is quite ancient. We do get reference of Mahesvara Siva appointing some Kshetrapalas, Yakshas Brahmas, Viras, Vinakas and Ganeshas in and around Banaras are none but the ancient folk gods who became gods under supreme god Siva. We get reference of the iconic representation of Siva Mahesvara having trident in his hand and standing beside a bull in first century CE on the coins of Kadphises group of kings bearing the epithet Mahesvara. ${ }^{49}$ It is believed that Siva worship in Banaras was in the form of folk cult. Perhaps Siva worship was well established during Gupta period in the name of Avimukteswara as it is corroborated by several seals from Rajghat excavation with inscription 'Avimuktesvara' ascribed to Gupta and post Gupta period upto $8^{\text {th }}-9^{\text {th }}$ centuries CE. The Matsya Purana ascribed to Gupta period also refers to the temple of Devadeva Avimukta. ${ }^{50}$ We have reference to temple of Vrishabhadwaja (may be Siva) in $8^{\text {th }}-9^{\text {th }}$ century CE in a book Kuttanimatam, written by Damodar Gupta, the minister of King of Kashmir Jayapida between 779-813 CE. In this book the author takes the Ujjain prince to Varanasi where he visits the temple of Vrishabhadwaja (Siva). ${ }^{51} \mathrm{He}$ further describes that the crowd that surrounded the temple abounded in prostitutes, women touts, actors and instrumentalists who accompanied the dancing girls. After worshipping the deity, the prince also took his seat in the midst of these people, and persons of the above description became attentive towards him. The merchants of the locality offered him betel $^{52}$ and scents. The story indicates that this temple had fame even outside Varanasi as far as Ujjain and Kashmir. ${ }^{53}$ The dancing girls (ganikas) continued to live in Varanasi all through the ages. There is a custom that all Hindu dancing girls go to the Adivisesvara temple once in a year on a fixed day and dance there whole night free of any charges. Existence of Vishvanath temple is attributed to $7^{\text {th }}$ century $\mathrm{CE}$ by scholars inferring from the accounts of Chinese

${ }^{45}$ Prinsep James. Benaras Illustrated in a Series of Drawings (introduced by OP Kejariwal) Vishvavidyalaya Prakashan. Varanasi; 1996. ISVN 817124176-x.

${ }^{46}$ Prinsep James. Benaras Illustrated in a Series of Drawings (introduced by OP Kejariwal) Vishvavidyalaya Prakashan. Varanasi; 1996. ISVN 817124176-x.

${ }^{47}$ Prinsep James. Benaras Illustrated in a Series of Drawings (introduced by OP Kejariwal) Vishvavidyalaya Prakashan. Varanasi; 1996. ISVN 817124176-x.

${ }^{48}$ Verma TP. The Temples of Banaras LK. Tripathi ed. Bharti, Bulletin of the College of Indology, BHU, 1871-84, p. 196.

${ }^{49}$ Brown CJ. The Coins of India. London, Calcutta; 1922, I 973, PI.IV.3.

${ }^{50}$ Matsya Purana. 184/9.

${ }^{51}$ The deity of this name is worshipped in modern days on the other side of the Varana river.

${ }^{52}$ Banarasi betels ( paan) are popular even today and are offered to guests as mark of respect. It is also used in worship as well as marriage as it is considered to be auspicious. We have many Hindi film song based on Banarasi Paan.

${ }^{53}$ Sukul Kuber Nath. Varanasi down the Ages. Patna: 1974. pp. 176-77. pilgrim Yuan Chuan. ${ }^{54}$ Many of the texts that detail the city's antiquity are composed after Mohammad Ghuri's invasion of the city and the first reported destruction of Vishvanatha temple in 1194 CE. ${ }^{55}$ The process of destruction of temples continued in the period of Aibak but in the period of Illtutmish and thereafter the process was slowed down and new temples were also constructed. ${ }^{56}$ AS Altekar, a historian, epigraphist, numismatist and archaeologist of early India, suggested that in ca. $1585 \mathrm{CE}$ the Vishvanath Temple was rebuilt, through the patronage of the Mughal Emperor Akbar, by Narayana Bhatta, a religious leader from Maharashtra who by then had become a resident of Banaras and was compiling his Trishthalisetu (a digest of Puranic verses on Kasi, Prayag, and Gaya). ${ }^{57}$ Altekar may have historicized correctly that the temple had been pulled down several times between ca. 1194 and 1669 CE, but he found no archaeological or literary references regarding the place where the original temple once stood. The only evidence of existence of the temple is inferred from HuenTsang's account. He ascribes to twenty Deva temples in the capital city at the time of his visit. The towers and halls of these temples were decorated with sculptured stones and carved wood. These temples were situated near river as he describes "pure streams of water encircled them" ${ }^{58}$ But Narayana Bhatta has proclaimed that prior to the building of the sixteenth-century Vishvanatha Temple; the Hindus had worshipped the site, and pronounced that this was so because either a previous temple, or more likely its powerful Linga, had existed here. Altekar supported this view. ${ }^{59}$ Of course archaeological excavations undertaken for a decade between 1959 and 1969 in the area to the far north-eastern border of the city known as Rajghat support evidence of the continuous occupational history for that area from $800 \mathrm{BCE}$ to $1200 \mathrm{CE}$. The excavations were undertaken by the excavators with the primary objective of finding the cultural sequence of the site with references to well-known literary background of Varanasi and it was observed by A.K. Narain and T.N. Roy that "sometimes in the twelfth century the site was in occupation by a set of people whose cultural equipment stood in marked contrast with that of the preceding period." ${ }^{60}$ And it indirectly supports the narratives which stand outside of the Puranic, Epic, Buddhist, and Jaina literary depictions of ancient Kasi, but we need to take up the challenge to archaeologically unearth Banaras to explore the past Brahmanical religious traditions and antiquity of a living city. We do not find accounts of medieval historians explaining Banaras as Brahmanical city except Al-Beruni who accepts the Brahmanical (Hindu) identity of Banaras. But many scholars in the nineteenth and twentieth century wrote histories of medieval Muslims destroying the ancient city. The explanations given for the destruction of temples by the zealous Muslim rulers ${ }^{54}$ Narain AK, Lalanji Gopal ed. Introducing Varanasi, published by Organizing Committee, XXXI Ameri History Congress, Varanasi, p. 38.

${ }^{55}$ Eck Diana L. Benaras City of Light. p. 85.

${ }^{56}$ Motichandra Kasi Ka itihas. Visvavidyalaya Prakashan. Varanasi; 1985. p. 186.

${ }^{57}$ Altekar AS. History of Banaras: From the earliest times down to 1937. Banaras; 1937.

${ }^{58}$ Beals S. Buddhist record of Western World. Vol II, Bk VII, pp. 44-45, 188$2 / 5$.

${ }^{59}$ Altekar premised his historicization of the location of two different temples on the "fact" that the practice [of Hindu worship of the Vishvanath] is exactly similar to the practice of the Buddhist pilgrims visiting Sarnath before the new temple was built in 1932. The whole of this settlement was devastated by the Muslims towards the end of the 12th century, and there was no Buddha image or temple at Sarnath for the last seven hundred years. Buddhist pilgrims nevertheless used to visit the place and offer homage to the empty sanctuaries and dilapidated shrines.

${ }^{60} \mathrm{Narain}$ AK, TN Roy. Excavations at Rajghat (1957-58 and 1960-65). Banaras Hindu University, Varanasi; 1976. p. 14. 
were the establishment of religious hegemony. But another theoretical explanation given by Richard Eaton is that such contestations were never religious alone. The Hindu temples were destroyed by the Muslim rulers because they serve the repositories of authority used to further their patron political ambitions. ${ }^{6}$ It was believed that the cause was not to establish religious hegemony, but they wanted to prove political supremacy over the earlier Hindu period.

After visiting the Ghats high expectations are raised about the city but when we move to the narrow dirty and crowded lanes it disappoints us. ${ }^{61}$ My memories of childhood came alive when I saw the narrow streets of Banaras recently. We do not see much of modernization in the streets, markets and houses in the old city of Banaras surrounding Ganges. 'Pre urban physical landscape with its natural forest cover was carved out by the Ganges and its left hand tributary streams, notable amongst which even today are the Varuna in the north and As in the south, forming the limits of the physical terrain of its habitat, the intermediate one have been designed as Godavari and Mandakini which are now invisible and could be earlier perceived as Ganga of the south and the Himalaya respectively; and a small rivulet joining the Ganges at the Harischandra Ghat perceived as Saryu of Awadh empire. The landscape was also dotted with a number of tanks most of which were drained by the above mentioned streams. The high concave bank of the Ganges formed the time concretion washed by perennial deep water channel did furnish a protective as well as attractive site for human occupation. ${ }^{62}$ Bathing in the Ganges is the first act of Banaras pilgrims and also daily rites for Banaras residents. Banaras is part of the wider polycentric landscape set amidst a pattern of symbolic signification linked with the tract of pilgrimages. Four kinds of Tirthas ${ }^{63}$ are mentioned: a. Sthala Tirthas or sacred localities; b. Jala Tirthas which include lakes, ponds, tanks, wells and vapis; c. Three rainy season rivers viz. Mandakini, Pitamah-srotika or Brahma $\mathrm{Nal}$, and Matsyodari; and d. Tirthas along the current of Ganges. Formerly the Ghats bore the name of Tirthas over which they stood. 99 such Tirthas are mentioned in the Puranas over the entire length of Ganges from Asi Ghat to Varana Sangam. ${ }^{64}$ The city's multitude of places of worship, its bathing platforms along the river Ganga, and its apparently unchanging religious traditions, moreover lent themselves particularly to invocations of a profound antiquity. ${ }^{65}$

Kasi (Banaras) is one of the seven cities that is moksadayaka; others are Ayodhya, Mathura, Haridwar, Kanchi, Ujjain and Dwarka. There is a belief that salvation is guaranteed to those who die at these pilgrim places. Although the layout design of Varanasi is multi shaped, it is dominated by an irregular network design of the town centre. ${ }^{66}$ Geographer RL Singh has been of the opinion that the network design has been on religious planning of the city, as around every important temple of the city there is a so called "Tirtha" which enables circulating pilgrimage. ${ }^{67}$ In ancient times Tirtha was literally a place to ford the river, and many of India's religious Tirthas are on the banks and at the confluence of its rivers. More broadly

${ }^{61}$ Recently some demolitions have taken place to expand the area around the Vishwanath Temple and make a corridor to reach out to the Ghats. Work is under progress.

${ }^{62}$ Singh RL. Benaras-A study of Urban Geography. 1955.

${ }^{63}$ Sukul Kuber Nath. Varanasi down the Ages. 1974. p. 195

${ }^{64}$ Sukul Kuber Nath. Varanasi down the Ages. 1974. p. 270

${ }^{65}$ Dodson Michael S. The Shadows of Modernity in Banaras. In: MS Dodson, editor. London, New York, Delhi: Banaras, Urban Forms and Cultural Histories; p. 145.

${ }^{66}$ Kockmann Uwe. Varanasi: Structural Components of a Pilgrimage City. In TP Verma, DP Singh, JS Mishra, editors. Varanasi Through The Ages, युगों युगों में काशी, Bharatiya Itihas Sankalan Samiti, UP; 1986. 327 p.

${ }^{67}$ Singh RL. Benaras - A Study of Urban Geography. 1955, 1966; p. 86 however the Tirtha are spiritual crossing place, ones prayers are amplified and ones rites are more efficacious, ones vows are more readily fulfilled. Titha place and Tirtha yatras are mentioned in the Vedas, Mahabharata, Ramayana, Puranas. The pilgrimage of Emperor Harsha to Prayaga and his distribution of all his gold and valuables are described elaborately in the historical accounts of his times, indicating the importance of pilgrimage during ancient period in the Gangetic region. ${ }^{68}$ The benefits of the Tirthayatras are often compared to the benefits one would gain from the powerful rite of sacrifices. The priest accompanying me to Dashasvamedha Ghat informed me ritual bathing on that Ghat bestowed the fruit of ten asvamedha yajna. As we all know there are 84 odd picturesque Ghats of Banaras. During my survey in the month of March during Holi festival the task of eye mapping of the Ghats through boat (not steamer, as steamer moves very fast) was undertaken. The boatman started from Asi Ghats and moved towards the other Ghats. It is told that there are ninety nine Tirthas within the current of the Ganges between the Varana Sangam and the Asi Sangam, the two ends of the Varanasi stretch of the Ganges and many of the ghats are named after them. Visit on the five Ghats which is known as Panchtirtha was conducted. They are as follows: Dashasvamedh Ghat, Lolark, Adi Keshava, Panch Ganga Ghat and Manikarnika Ghat.

The Dashasvamedh Ghat has been famed for centuries. Bhaira Sivas are mentioned in the Vakataka grants as imperial dynasty who were crowned with the holy water of the Ganges and took the ceremonial baths on the Ganges at the end of ten Asvamedha sacrifices. On this account Dashasvamedha Ghat ${ }^{69}$ at Banaras was so named. ${ }^{70}$ Kasikhanda gives different story about creation of Dashavamedha. According to this text formerly the Tirtha was called Rudrasaras, but as Brahma performed ten Asvamedhas, it came to be called Dasavamedha. ${ }^{71}$ Manikarnika ghat, also called the naval of Banaras, ${ }^{72}$ is situated in the midway along the Ganges between confluence of the Asi and the Varuna. It marks the southern boundary of the sacred city. It stands at a dividing line between two equal divisions (khands) of the city: Shiva khand to its north and Vihnu khand to its south. Cremation ground is focal point of the city. According to the description in Kasikhand ${ }^{73}$ Vishnu was creation of Siva and Parvati to perform the task of creation of universe. Vishnu dug a tank with his disc and filled it with sweat of his terrible austerities. On their visit, seeing Vishnu burning with fire of asceticism, Siva was delighted and his earring dropped off into the Vishnu tank, which Shiva announced henceforth to be known as Manikarnika (jewel of the ear). Near Manikarnika pool is the temple of Tarakesvara so named from the belief that Siva will whisper the mantra called Taraka in the ear of dying man brought to the sacred pool. ${ }^{74}$ Manikarnika is also called mukti kshetra ${ }^{75}$ and is considered to be the holiest among all the Banaras Tirthas. Panchganga ghat is supposedly the meeting place of five rivers viz. the Kirana, Dutapapa,Ganga, Yamuna and saraswati(though four of them are invisible).

${ }^{68}$ Harshacarita of Bana, trans. Cowell and Thomas 1897, Bk Iv.

${ }^{69}$ Fleet JF. Dudia Plates of Pravarasena II, Epigraphia Indica Vol III, p.258 and Fleets Gupta Inscriptions Corpus Inscriptionum Indicarum, p.236 and p.245.

${ }^{70}$ Jaiswal KP. History of India 150 AD-350 AD. Low Price Publication, new ed. of 1933, 1996, p.5

${ }^{71}$ Skanda Purana Pt. 10-11, Kasikhanda; 1996; 1997. Translated and Annotated by G.V. Tagare, Motilal Banarasi Das, Delhi, Chapter 52, 66-68.

${ }^{72}$ Darian Steven. A Ganges of the mind: A Journey on the river of Dreams, Ratna Sagar, Pvt. Ltd, Delhi, 1988. p 132.

${ }^{73}$ Skanda Purana Pt.10-11, Kasikhanda; 1996; 1997. Translated and Annotated by G.V. Tagare, Motilal Banarasi Das, Delhi, chapter 28.

${ }^{74}$ Kane PV. History of Dharmasastras. Vol IV, p. 636.

${ }^{75}$ Kane PV. History of Dharmasastras. Vol IV, p. 635. 
Many copper plate grants of Gahadvala rulers speak about the grants on Adi Kesava Ghat, one by king Mahendrapala on the occasion of sun eclipse after Maharani Prithvistrika took bath, ${ }^{76}$ other by Govindacandra in $1131 \mathrm{CE}$. Another grant was made by Candradityadeva who after bathing at Adi Kesava Ghat at the confluence of river Ganges and Vaurna bestowed on 500 Brahmans 30 villages on the akshaya tritiya on samvat $1156 \mathrm{i}$, e, $1099 \mathrm{CE} .{ }^{77} \mathrm{We}$ have copper plate grants stating grants to various other ghats, such as grant of village after bath at Kapalmochana ghat in $1121 \mathrm{CE},{ }^{78}$ grants made on a queen taking bath at the ghat of god Vedesvarain Avimuktakshetra ${ }^{79}$ grant to Lolark temple by Jayacandra in $1173 \mathrm{CE}$, five copper plate grants of Govindacandra in $1156 \mathrm{CE}$ after a bath at Koti-tirtha on Uttarayana-sankranti. ${ }^{80}$ What is noticeable in Banaras is that the priestly influence is very powerful. As per census reports of 2011 the Brahmin caste were not fewer than from twenty to twentyfive thousand. ${ }^{81}$ They have control over the Temples, Ghats, the sacred wells, streams, and reservoirs, and other holy places about the city. They conduct the worship of the people, and give directions respecting the numberless ceremonies which are performed. Every sacred spot has some peculiarity connected with it; and it is of great moment that no punctilio should be omitted. They receive the offerings, the alms, the public dinners, and the good things which devotees are every ready to bestow in return for gaining merit by worship. Sherring in his monograph also gave this description about the religiosity of the city in colonial period that "Her thousands of temples, her myriads of idols, her swarms of pilgrims, her hosts of daily worshippers, together with the pomp and circumstance and multifarious representations of idolatry, in their vast aggregate, cause the Hindu religion to be visible to the eye, in this city, in a manner and degree unknown elsewhere". ${ }^{82}$ Along the Ghats strange figures of religious mendicants and ascetics are to be seen, some superintending the ablutions of the pilgrims in the sacred stream of the Ganges, while others practice devotions or various forms of austerity. After eye mapping by boat, my concentrated visit to the five ghats which are considered as Panchatirthas helped me understanding the pilgrim place in its socio religious context. In most of these ghats the dominant presence of male members of the society was explicit discerning the patriarchal culture of India. But we could notice that the pilgrims were not alone in many cases the whole family accompanied the religious bathing. The visibility of religious activities at these Ghats reminded me of Lewis Mumford's monograph "The City in History" where he writes that "city is energy converted into culture". ${ }^{83}$ Banaras is also such city converting the energy of the mankind into dominant culture.

The study of Varanasi as pilgrim centre contributes substantially to understanding the roles religions play in maintaining and modifying social systems as well as in facilitation or impeding relations between members of different societies. The social formations at Varanasi gauge for measuring the complexity of societies and thereby play at part in constructing a typology of social forms ${ }^{84}$ Our study of a

\footnotetext{
${ }^{76}$ Journal of Royal Asiatic Society. 1896. p. 787.

${ }^{77}$ Epigraphia Indica. Vol. XIV, p. 197.

${ }^{78}$ Epigraphia Indica. 21 Copper plate of Gahadvalas. Vol. IV, p. $97 \mathrm{ff}$.

${ }^{79}$ Epigraphia Indica. 21 Copper plate of Gahadvalas. Vol. IV, p. 144

${ }^{80}$ Epigraphia Indica. 21 Copper plate of Gahadvalas. Vol. IV, p.144.

${ }^{81}$ Census Report 2011.

${ }^{82}$ Sherring MA. Benaras The Sacred City of The Hindus in Ancient and Modern Times. BR Publishing Corporation. Delhi, 1868, reprint 1975, p.17.

${ }^{83}$ Momford Lewis. The City in History: it's Origins, its Transformations, and its Present, New York, Harcourt, Brace and World Inc, 1961, p.570.

${ }^{84}$ For the anthropological concept see Glen Bowman, Anthropology of Pilgrimage in Dimensions of Pilgrimage, An Anthropological Appraisal, ed. by Makhan Jha, Inter India pPublications, 1941, p. 2.
}

Brahmanical sacred site, Varanasi, also known to Hindus as Kasi, or the city of light follows in this tradition of humanistic approaches to the study of pilgrimage. Varanasi being city of religious and cultural importance became centre for a variety of religious fairs and festivals at Ganges, temples, and other places. Even within (and also outside) the Brahmanical religion several different levels of diversitiesdiversity of categories, diversity of performances, diversity of performers, diversity of regional cultures is sacrosanct and visible in Varanasi. Two types of pilgrims come to Varanasi; Visitant from the surrounding areas who disperse after the festive seasons and second those who desire to make complete pilgrimage, stay for longer duration for nagar pradakshina, or circuit of the temples, involves a visit to all the thousand Shivalas, perform rites at each sivalaya with prayers and perambulations. This tradition which prevails even today is quite ancient and has also been mentioned by James Prinsep. ${ }^{85}$ There is a proverbial saying regarding the pilgrimages of Kasi, Prayag and Gaya: "Kasi hunde,Prayag munde and Gaya dunde" meaning at Kasi "devotees keep moving, walking and praying, at Prayag devotees shave(mundan) at the confluence of Ganges as there is a notion that devotee will be blessed and at Gaya the devotee has to pay hefty to the Brahmanas for nirvana or mukti. 'The uniqueness and distinctiveness of a place are the special aspects of a sacred place where genius loci and values of human environment are deeply rooted and maintained by means of sacred ways-as reflected in pilgrimages and associated performances and rituals. The quality of the sacred place depends upon the human context that has been shaped by it, with respect to memories, experiences, miracles and expectations. The city of Varanasi is unique in the architectural, artistic and religious expressions of traditional Indian culture and is a living example of this culture even today. The cultural heritage of the city is 'special' and is an exceptional testimony to living traditions, to be seen and to be believed, in religious faith, rituals and myriad festivals, traditional forms of worship and belief that are still practiced, asceticism, spiritual exercises, education, music, dance, handicrafts and art forms that continue to be transmitted through generations'. ${ }^{86}$

Religion may be regarded as paramount source of supply -the staple stickles of commerce through which the holy city flourishes and is enriched. ${ }^{87}$ The pious faith in the efficacy of Kasi and the purifying virtue of Ganges and belief of people of deemed admittance into Siva's heaven to be secured to them if they die within the limits of Punchkroshi (five koss) circle about the town. The Hindu Tirtha varies in their potency and some are more powerful in their effect than others. For instance while the Siva at Baidyanath dham is called the Manokamanalinga (giver of all material benefits), the Shiva at Kasi is believed to bestow upon the visitors the salvation, for it is called the Mokshadaini Siva. ${ }^{88}$ At great occasions such as eclipses of the sun or moon or favourable conjunctions of the planets, incredible multitudes flock in from all quarters to bathe at consecrated ghats of the sacred river. The visitants from the environs on such occasions disperse as soon as the ceremony is over, but to those who desire to make a complete pilgrimage, a stay of longer duration is necessary for the nagar pradakshina, or circuit of the temples, involves a visit to all thousand Shivalayas, at each of which there are rites to be performed,

\footnotetext{
${ }^{85}$ Prinsep James. Benaras Illustrated in a Series of Drawings. (Introduction by O.P. Kejariwal), 1833, reprinted 1996. p. 15, ISBN81-71-24-176-X.

${ }^{86}$ Singh Rana PB. Banaras: Making of India's Heritage City. Preface, Cambridge Scholars Publishing, UK. 2009.

${ }^{87}$ Prinsep James. Benaras Illustrated in a Series of Drawings, (introduction by O.P. Kejariwal), 1833, reprinted 1996, p. 15, ISBN81-71-24-176-X.

${ }^{88} \mathrm{Jha}$ Makhan. Origin, type, spread and nature of Hindu pilgrimage Makhan Jha edt., Dimensions of Pilgrimage, an Anthropological Appraisal, Inter India Publication, Delhi,1985, P. 14
} 
with prayers and perambulations An historical investigation of the evolution of pilgrimage at Varanasi would show how it is closely integrated with the social practices of their cultural environments such as functions at ghats bathing dressing praying preaching lounging gossiping or sleeping were universalized religious practices. An anthropological study which treated pilgrimage as a means of channeling the sacred power of a mythic time or realm into the social structure of the contemporary world would be able to link its investigations with enquiries into the changing place of religion in the maintenance of society, the place and power within society of groups which support pilgrimages, the motives of religious groups and states which promulgate pilgrimages and so on. ${ }^{89}$ The population of Banaras includes a large number of pilgrims and hence it is liable to considerable fluctuations.

There is a network of sacred journey (yatra) of Kasi as a Tirtha place as mentioned in the Puranas and the mahatmya granthas. These yatras link different shrines of Kasi and these have been classified into different criteria: ${ }^{90}$
a. Panchakroshi yatra
b. Antargrihi yatra
c. Trikona yatra
d. Ayatan yatra
e. Nakshatra yatra

These are the space related yatras. The total distance covered in Panchakroshi yatra is radius of about five kroshas $(80 \mathrm{kms}) .^{91}$ The sacred journey starts from Manikarnika Ghat (Mukti Mandap) and ends there and it encompasses all the focal shrines of Kasi Kshetra, the four Dhamas, seven Puris, fifty six manifestations of Ganesh, nine Gauris, thirteen Narsingha, sixteen Kesava, including Rama and Krishna, and other incarnation of Vishnu, twelve Adityas eight Bhairava, and a very large number of Siva Linga. By covering this yatra symbolically one covers the whole earth. There is a Panchkroshi temple in the city which has same merit as the Pachakroshi circumbulance, for those who are incapable of performing the actual parikrama. This parikrama also acquires the same spiritual merit as the original Panchakroshi marg. This temple documented in detail by anthropologists and architect Neils Gutschow was probably built in $19^{\text {th }}$ century as a three dimensional built up map of the whole sacred zone. ${ }^{92}$ It is encircled by 273 individual shrines, each providing symbolic duplicate of one of the stations along the Panchkroshi road or one of the other sacred sites in the zone of Kasi. The central sanctum has a Linga 'the Dvadashaeshvara' (the twelve lord Linga), a single Linga representing all twelve Jyotirlingas in one place. The visitors who met us on the way narrated their spiritual gain through the circumbulance of Panchakroshi temple. A scholar describes that 'Sacred spaces are not generated by maps, in spatial texts, or defined by surveying physical space. Rather, they are stamped out by the very feet of the pilgrims over the course of their circumbulations. It is the pilgrims' spatial

\footnotetext{
${ }^{89} \mathrm{Jha}$ Makhan. Origin, type, spread and nature of Hindu pilgrimage Makhan Jha edt., Dimensions of Pilgrimage, an Anthropological Appraisal, Inter India Publication, Delhi, 1985 , p. 6.

${ }^{90}$ Saraswati, Baidyanath. Kasi Pilgrimage-The end of endless journey, in Makhan Jha edt., Dimensions of pilgrimage, p. 95.

${ }^{91}$ Hariscandra, Bharatendu, Panchakroshi ke Marg ka Vichar, 1872, it was reprinted in Ramnagar in 1997 with poem Pancakrosha Sudha added to its appendix.

${ }^{92}$ Gutschow Niels. Benaras: The Sacred Landscape of Varanasi. Stutgard, Axel Merges, 2006, p. 113-79.
}

practice that creates and defines sacred spaces. ${ }^{93}$ Panchacroshi is not unique pilgrimage and is replicated in Ayodhya, in Omkareshwara on the Narmda river, on Mount Brahmagiri in Maharashtra, and at many other places as it is studied by Diana Eck. ${ }^{94}$ Another yatra prescribed is Antargrihi yatra or parikrama which begins from Manikarnika and ends at Muktimandapa. The extensive mapping of Hindu sacred geography,with its intricate network of pilgrimage routes was already in place in pre-Islamic period that had sought to construct the symbolic unity of India as expressed by Bayly. ${ }^{95}$

\section{Actors and Agents as vehicle of religious traditions and social change in the cultural landscape of Banaras:}

Let us examine the space and social relations between important actors or agents of cultural landscape of Banaras: Space is defined and conceptualized in accordance to social structure; that means boundaries are social, not spatial, and perceptions are constructed via processes of social positioning and affiliation and have thus particular social forms. Important factors or agents in the social landscape are the various caste groups Rulers, Brahmanas, Kewats, Washermen, Traders and Merchants and Chandalas (the caste performing cremation of dead ) and these groups have influenced the religiosity and culture since the ages. Brahmanical Banaras in Vedic period was a caste based society and it continues as a pan Indian phenomenon and it functioned on prescribed format. Radcliffe Brown compares the social systems with the complex organism, such as a human body having structure as an arrangement of organs, tissues and fluids. The interrelatedness of the customs and institutions of social and religious system gives them life. Like the human body each society possesses a degree of functional unity because all parts of the system work together without producing persistent conflicts. He calls this working hypothesis of functionalism ${ }^{96}$ and it becomes the task of investigator to establish the function of socio religious activities. In Banaras, the arrangement of space and social relations of various social groups such as Brahmana, Kshatriyas, Kevats, Merchants, Washermen and others in caste boundaries emphasizes the importance of collective organization to cope with the mundane reality of everyday life. It represents collective efforts to contend with and manage their place and position in urban society and is an essential asset for achieving a life of security and content. These relations are socially and historically constructed and denote power relations amongst the community and beyond it. Any attempt to elucidate the social and spatial topography of the various caste groups must therefore be anchored in indigenous connotations of space, spatial relations and social organization. ${ }^{97}$ As Banaras is religious centre, Brahamanical or priestly influence is exceedingly powerful. They have control over the temples, sacred wells, streams, and reservoirs and other holy places about the city. They receive the offerings (dana) and alms and bhoja (public dinner). ${ }^{98}$ Banaras has

${ }^{93}$ Gengnagel George. Maps and processions in Banaras: The debate concerning Panchakroshi Yatra, in Martin Gaenszle and Jorg Gangnagel edt. Visualising Space in Banaras, Images, Maps, and the Practice of Representation, Oxford University Press, 2008, ISBN139780195695700, p. 159.

${ }^{94}$ Eck Diana L. India: A Sacred Geography. New York: Harmony Books; 2012. p. 3 .

${ }^{95}$ Bayly Christopher Alan. Rulers Townsmen and Bazars: North Indian Society in the age of British Expansion, 1770-1870. New York: Cambridge University Press; 1983. p. 125.

${ }^{96}$ Radcliffe Brown. Structure and Function in Primitive Society. Free Press, Glencoe, Illinois, 1952;178-81.

${ }^{97}$ Stefan Schute has expressed this concept in his study on the ghats or social landscape of washermen (Tat) of Banaras in.

${ }^{98}$ Sherring MA. Benaras The Sacred City of The Hindus in Ancient and Modern Times, BR Publishing Corporation Delhi, 1868, reprint 1975, p.16. Sherring describes the functions performed by the Brahmanas. 
long been considered a Brahminical stronghold, as Parry observes: 'With its reputation for 'orthodox' Brahmanical Hinduism and its ancient tradition of Sanskritic learning, it is the Brahmans who set the dominant religious tone of the city... It is they who actually conduct the rituals prescribed by the texts, who expound their meaning, and who in this sense mediate between the textual tradition and the theologically untutored'. ${ }^{99}$ This is not to say that the Brahmins of Banaras are a homogenous group. In fact, as Parry shows, the relative status of Brahmins differs quite markedly according to one's occupational status, both within the ritual economy of Banaras and outside of it. ${ }^{100}$ Tradition of learning also remained closely connected with the Brahmanical ritual activities. Despite the destruction of temples in medieval times Kasi remained a religious place as is evident from the works of famous Nibandhakara Lakshmidhara Bhatt who compiled the authoritative digest Krityakalpataru in $12^{\text {th }}$ century and Narayan Bhatt who compiled Tristhalisetu in $16^{\text {th }}$ century and Kamalakar Bhatta's work Nirnaya Sindhu in $17^{\text {th }}$ century. ${ }^{101}$ Eck in her preface writes that the Brahmans as knowledge keepers of the tradition....act as interpreters of myth and Mahatma. They include... pundits (teachers), pujaris (temple priests) pandas (pilgrimage priests), mahants (heads of a large temple complex) and vyasas (storytellers). ${ }^{102}$

Since Vedic period we have different categories of Brahmanas performing different types of duties as such Brahmana srotriya priests who performed rituals, Kavis (poets) that would probably have included brahmanas or bards. In Rgveda there is overlap between the functions of priests and kavis. In Aryan fold of religion two kinds of practices prevailed, one followed by Dvijas, i.e, Brahman Kshatriya and Vaisyas ${ }^{103}$ who were entitled for the study of Vedas and practice of higher form of religious worship prescribed for them and those practiced by the sudras. In Banaras there were roughly two categories of Brahmins, one who were attached to temples, conduction rituals and guiding pilgrims and the second category comprised those engaged in the study of Sanskrit and spread the knowledge of scriptures. Modern day Brahmana engaged at temples and in pilgrim-related services again are divided into three categories:

a. Pandas, Tirtha purohits and Yatrawals;

\section{b. Ghatiyas and}

c. Purohits. Naukul Sardars-nine classes of Kanauj Brahmins, surnamed Mishra, Pathak, Chaturvedi, Shukla, Pandey, Upadhyaya, Dube, Tewari, and Agnihotri-could be Tirtha purohits and only Sarayupariya and Gauda Brahmins could be Jurnihars or Yatrawals. ${ }^{104}$

However, these distinctions were not always maintained, and there were cases wherein these agents became the masters in time and the former, in turn, appointed their own agents for collecting and attending to pilgrims. Pandas are the priests in the temples. Tirtha purohits, also known as TirthadhYakshas or Tirthadhikaris, were Gangaputras, who exerted control over the deities and sacred spots, including holy tanks, wells and the Ganga itself. They accommodated the pilgrims in boarding houses, either owned or hired for that purpose, and looked

\footnotetext{
${ }^{99}$ Parry Jonathan P. Death in Banaras. 1994;33-34.

${ }^{100}$ Parry Jonathan P. Death in Banaras, p.71-74.

${ }^{101}$ Dalmia Vasudha. The Nationalization of Hindu Traditions. Bharatendu Harischandra and Nenteenth century Banaras. p. 96.

${ }^{102}$ Eck Diana L. Banaras: City of Lights, Columbia university press. 1983.

${ }^{103} \mathrm{Rg}$ Veda, X.7I.II.

${ }^{104}$ Medhasananda Swami. Varanasi at the Cross Roads. The Panoramic view of Early modern Varanasi and Survey of its Transition, Ram Krishna Mission Institute of Culture. Kolkota, 2002, ISBN 81-87332-18-2. 338 p.
}

after and gave them guidance. Their jurisdiction over the pilgrims, based on place of nativity and caste, was hereditary. They would maintain records of these pilgrim-clients as an essential part of their profession. As such, these records were goldmines of information regarding pilgrim names, divisions and sub-divisions of castes, their parents and grandparents, places of residence, dates of visits, etc. ${ }^{105}$ The second sub group among the Brahmanas are Ghatiyas who would sit on the ghats, usually under big umbrellas, and attend to the bathers. Ghatiyas put tika (holy sign) on the foreheads of devotees after their bath. The third sub caste is the Purohit. However, these distinctions were not always maintained, and there were cases wherein these agents became the masters in time and the former, in turn, appointed their own agents for collecting and attending to pilgrims. This led to oppression and harassment of pilgrims in number of ways specially extracting money from the pilgrims. ${ }^{106}$

Another important actor on the Ghats of Banaras is the boatman or Ghatwar/Kewat also known as Mallah. They belong to two categories: resident boatman and non-resident boatman. I was told that the resident boatmen known as Ghatwars have right to operate boats on the Ghats, while the non-resident boatman known as Mallah worked as casual labour for the later without having residential rights. This is indicator of social distinction and occupational position within the boatmen community. The Ghatwars of Varanasi claim their ancestry from ancient times. They refer to the relation of Rama and Kewat in the Ramayana. The Kewats say that formerly the Hindus would not take water from them; but on one occasion during his exile Rama came to them and asked them to ferry him across the river; before doing so they washed his feet and drank the water, and since that time the Hindus have considered them pure and take water from their hands. Historians claim that this story has no doubt been invented to explain the fact that Brahmans will take water from non-Aryan Kewats, the custom having in reality been adopted as a convenience on account of their employment as palanquin-bearers and indoor servants. ${ }^{107}$ Doron argues that the Kewats were denied their agency, subservient to the cultural logic in which it is the upper caste Hindus who, for practical reasons, accommodated this myth as a matter of convenience. ${ }^{108}$ But never the less the mythology of boatman (Kewat) and his caste purified by the divine prince Rama, does suggest at least the potential for fluidity, transformation and change within the caste system. Within the ritual economy of Banaras, boatmen have a significant role of providing boating services to the many pilgrims arriving at the city. They closely interact with Brahmin priests, earning their income from what is a transient population of tourists and pilgrims. It is against this historical context that interpretations of myth become particularly illuminating of a creative and meaningful cultural process, in which boatmen seek to assert their access to material resources and claim a more esteemed status in the Hindu socio-religious order.

A class of actor in the Brahmanical religious milieu, though away from the caste-fold is that of Aghoris or Augars who believed in tantric magic and ceremony of calling up demons at the burning Ghats. Their names are derived from the Sanskrit word Aghora, one of the titles of Siva. There are many monasteries or maths in Mount Abu

\footnotetext{
${ }^{105}$ Medhasananda Swami. Varanasi at the Cross Roads, The Panoramic view of Early modern Varanasi and Survey of its Transition, Ram Krishna Mission Institute of Culture, Kolkota, 2002, ISBN 81-87332-18-2. P. 338

${ }^{106}$ Cases have been reported in British Period and later.

${ }^{107}$ Russell RV, Hira Lal. Tribes and Castes in India. (4 Vols.), vol. 3: London, 1916, pp. 423-4

${ }^{108}$ Doron, Assa, Ferrying the Gods: Myth, Performance and the question of 'Invented Traditions' in the city of Banaras.
} 
(Rajasthan), Mount Girnar in Kathiawar, Bodh Gaya and Banaras. ${ }^{109}$ The Banaras sect claims its association with Kinnaram who was introduced to Banaras by Kalu Ram an ascetic of Girnar towards the end of $18^{\text {th }}$ century. ${ }^{110}$ Another class of actors was the courtesans who had occupied space in public life since ancient times and there were references to them in Buddhist text Jatakas and also in various Sanskrit works. ${ }^{111}$ The best known courtesans who became famous for her beauty and art of dance, music and singing, exercised great social power, and played a significant role on public occasions, even till later date. She was asked to appear in the court of Banaras on auspicious occasions and also in the prominent temples and ghats of the river Ganges. During worship of Ganga the songs of these women formed an essential part of the ritual. Modern historian E.B. Havel ${ }^{112}$ also mentioned the central role of the courtesans in the culture of the city. According to the census of 1827 there were 264 hindooee and 500 musalmani professional nach girls (courtesans) in the town. ${ }^{113}$ Bhartendu Harischandra also registered their presence in $19^{\text {th }}$ century and wrote a play Prem jogini (Yogini of Love). ${ }^{114}$ MA Sherring, who stayed in the city for more than a decade has offered a detailed account of the caste structure of Varanasi during the middle of the nineteenth century which would help us to analyze the functioning of the complex caste structure in the city. He writes that Varanas appeared a "very favourable spot" for the commandment of such a work as "representatives from all castes of India come up to the sacred city.......perhaps no city in the world draws to itself such a motley of assemblage of tribe and tongues." 115 The census of 1871 estimated that the population of the town to be 175185 , out of which 151485 were Hindus, 51667 were Muslims, 646 Christians, 343 Jains, 108 Sikhs and rest of them were Parsis and Buddhists. The total area of the city was 6162 acres giving an average population density of 21742 per square mile. ${ }^{116}$ Varanasi presents national characteristics, since people from different parts of India have settled and occupied various professions. Though it has been called stronghold of Hinduism on the basis of its population and religiosity, but other communities also occupy large spaces.

\section{Debating myth and historicity in sacredness in Brahmanical Banaras}

Scholars have often debated the religious tradition of Banaras and also labeled Hindu tradition as invented tradition in eighteenth and nineteenth centuries. They pointed out the centrality of the classicization of tradition to the nationalist project. ${ }^{117}$ Vasudha Dalmia points out that 'the historicization and admentation of the(these) traditions into a more or less unitary continuum came into being in interaction with the British, who wished in their turn to benefit by andif not entirely appropriate, at least participate in the patronage of both the sacred and learned traditions. ${ }^{118}$ Scholars points to hidden political

${ }^{109}$ See article on Aghori by Hastings in Encyclopedia of Religion and Ethics Vol. 1 and Tantricism, Vol. 12.

${ }^{110}$ Ibid. also, Newby Eric, Slowly Down the Ganges , Hodder and Stoughton, Great Britain, p. 228 fn, 1996.

${ }^{111}$ Motichandra, Courtisans in Ancient India, 1962. p. 46, 89, 145.

${ }^{112}$ Havel EB. Benaras: The Sacred City, Thacker \& Co. London, 1905.

${ }^{113}$ Prinsep James, Benaras Illustrated, p. 33.

${ }^{114}$ Dalmia Vasudha. The Nationalism of Hindu Traditions Bharatendu Harischandra and Nineteenth century. Banaras University Press; 1997.

${ }^{115}$ Sherring MA. Hindu Tribe and Castes as Represented in Benaras. p. 1.

${ }^{116}$ Nevill HR. Benaras A Gazetteer, District Gazetteer of United Provinces of Agra and Oudh, Vol XXVI, Government Press, United Province, 1909. p. 433.

${ }^{117}$ Chaterjee Partha. The Nation and its Fragments. Princeton University Press 1993, p. 73; Madhuri Desai, Mosques, Temples, and Orientalists: Hegemonic Imaginations in Banaras, TDSR, Vol. XV Number 12003.

${ }^{118}$ Dalmia Vasudha. The Nationalization of Hindu Traditions, Bharatendu agenda of the colonial and post-colonial rulers in mystifying Banaras and labels it as hegemonic imagination. ${ }^{119}$ Nicholas Dirks believes that fanciful "texts" do identify key elements of political action and signify moments in indigenous thought about the past, and that the religious and the political cannot be separated. If myth has to be seen as a part of historiographical possibility and a distinctive way of establishing sequence and relevance in the understanding and representation of past", then at the very least, the memory of Banaras' mythical past has informed much of its remaking". ${ }^{120}$ The mythical tradition of ancient Banaras as described in Kasikhanda, continued to be patronized by the Brahmanas and later Rajas of Kasi who facilitated the religious activities of thousands of pilgrims who continuously visited the temples and ghats throughout the ages. Most of the ancient historians have looked for the sources in Itihasa Purana in search of historicity of ancient India and Banaras is part of it. We should understand that the religious traditions across the world have mythical origin. The Hindus derived their ancestry from the mythical tradition connected with Kasi and it continued in medieval period despite disruptions during the Muslim rule and the British rule evolved a parallel tradition which glorified and mystified the timeless ritual and the learned tradition of the city. The old mystified Brahmanical tradition (the Vedic dharma) was consolidated over a period of time, the reference of which we get the Vedas, Epics, Puranas and many other ancient, medieval and modern historical sources which we have discussed above. The Brahmanical religion developed a synonymous name Hindu religion after the Muslim invasion. Alberuni in eleventh century concentrated on the belief and practices of Brahmanas and it was his view that "the main and most essential point of the Hindu world of thought is that which the Brahmana think and believe, for they are especially trained for preserving and maintaining their religion. ${ }^{121}$ Generally there is assumption that Hinduism is served as Brahman way of life. But the Brahmanical culture must be understood in the broad sense as referring to beliefs and practices that are far from homogeneous but which have been propagated and ratified by the Brahmanical authority. Brahmanical culture includes atheism, agnosticism and theism, monism, monotheism and polytheism, traditional caste practices and their rejection and reinterpretation, Vedic ritual and tantric Bhakti religion, and widely divergent understanding of Hindu Dharma. All these things, in innumerable combinations within the vast fabric of Hinduism have been in some form or their approved, defended, prescribed and standardized by often conflicting or contending sources of Brahman authority. ${ }^{122}$ Banaras being a centre of Brahmanical religion, we must understand Brahman and non-Brahman Hindus alike have articulated their identity in terms of Brahmanical or Hindu culture and its religiosity. Banaras has been established as a major pilgrimage centre of India with distinct Brahmanical consciousness expanding throughout the commercial routes to the remotest villages from Nepal to South India.

\section{Acknowledgment}

I acknowledge my gratitude to my University (University of Delhi) for research grant for the project to work on Benaras. I thank Dr. Vikas Singh, Assistant Professor Department of History, Prof Rana

Harishchandra and Nineteenth century Banaras. New York: Oxford University Press, Delhi; 1997. p. 143.

${ }^{119}$ Desai Madhuri. Mosques, Temples, and Orientalists: Hegemonic Imaginations in Banaras, TDSR, Vol. XV Number 12003.

${ }^{120}$ Dirks NB. The Hollow Crown: Ethno History of an Indian Kingdom. Cambridge: Cambridge University Press; 1988, p. 58.

${ }^{121}$ Alberuni's India, Ed Sachau, 1888, 39, n. 9

${ }^{122}$ Lipner Julius. Hindus: Their Religious Beliefs and Practices. New York: Routledge, London; 1994. p. 9. 
P. B. Singh, Department of Geography, both in BHU for scholarly discussion on Varanasi, Dr. Kumar Shailesh Singh from Banaras, my colleagues from the department for helping me in various ways, pilgrims unknown to me, the priests, boatman and the guide and informants who narrated various stories about the pilgrimage city. I also acknowledge the Central Reference Library, University of Delhi, Indian Council of Historical Research Library, National Museum Library, Nehru Memorial Museum Library and Banaras Hindu University Library for the wealth of texts I used for my research work.

\section{Conflicts of interest}

Author declares that there is no conflict of interest.

\section{References}

1. Grieves Edwin. Kasi: The City Illustrious, or Banaras. Allahabad. 1909. $6 \mathrm{p}$.

2. Sherring MA. Sacred City of the Hindus: an account of Banaras in Ancient and Modern Times, reprint. London: Trübner \& Co. 1868; 6-7.
3. Eidt RS. Detection and Examination of Anthroposols by Phosphate Analysis. Science. 1977;197(4311);1327-1333.

4. Havell EB. Benaras the Sacred City, Sketches of Hindu Life and Religion, Blakie and sons. London, Glassgow, Bombay; 1905.

5. Singh Rana PB. Banaras: Visioning Cultural Heritage \& Planning. SANDHI (IIT Kharagpur). 2015;1(1):110.

6. Eaton RM. Temple desecration and Indo Muslim States. Frontline. $2001 ; 17(25-26)$ 